\title{
Uma crítica francesa acerca do espaço urbano
}

Perci Coelho de Souza*

Resumo: A dimensão espacial urbana foi objeto de uma polêmica teórica que ganhou maior visibilidade no meio acadêmico com a entrada em cena da Escola Marxista Francesa em meados dos século passado. Este texto apresenta um recorte do itinerário acadêmico de alguns de seus principais interpretes de primeira geração discutindo seus pontos de convergência e divergência em relação aos fundamentos marxistas. Admite-se que na contemporaneidade a problemática espacial-urbana vem sofrendo novas inflexões de natureza teórica, mas nem por isso, o rigor e fundamento dessa escola francesa perde vitalidade, pelo contrário, muitas de suas categorias são renovadas e imprescindíveis para explicar a dinâmica territorial do capital escamoteada pela ideologia da "globalização".

Palavras-chave: Sociologia Urbana, espaço urbano, revolução urbana, marxismo.

* Assistente Social. Doutor em Serviço Social pela Universidade Federal do Rio de Janeiro, Mestre em Política Social pelo Programa de Pós-graduação em Política Social da UnB. Integrante do Grupo de Pesquisadores do CNPq Locuss. E-mail: perci@ unb.br

Este texto sistematiza alguns dos principais argumentos contidos no primeiro capítulo da tese de doutorado Potencialidades políticas nas práticas de comunicação da CUT: o uso da Internet e o Platô Informacional do DF, defendida na Universidade Federal do Rio de Janeiro (UFRJ), em dezembro de 2005. 


\section{A French criticism over the urban space}

Abstract: The urban space dimension was object of a theoretical controversy that gained greater visibility in the academic field inspired by the French Marxist School, in the middle of the last century. This text presents a clipping of the academic itinerary of some of the main interpreters of the first generation, exposing their points of convergence and divergence in relation to the Marxist ideology. One admits that nowadays, the space-urban problematic is suffering new inflections of theoretical nature; however, the rigor and the ideology of this French school does not lose vitality, on the contrary, many of its categories are renewed and essential to explain the territorial dynamics of the capital concealed by the ideology of "globalization".

Keywords: Urban sociology, urban space, urban revolution, Marxism.

\section{Introdução}

Devemos aos estudos franceses da segunda metade do século passado, um movimento do pensamento sociológico de crítica à tradição empiricista para o tratamento do espaço urbano. Essa renovação teórica, também conhecida como a "nova sociologia urbana" ganhou projeção nos meios acadêmicos a partir dos anos de 1960 dando início a um fecundo processo de conversão da análise desse objeto. Esses estudos desnudaram o problema que a Escola de Chicago, (até então hegemônica nas pesquisas sobre a cidade industrial), se recusava a enfrentar, isto é, como se operam os processos de segregação socioespacial condicionados pela lógica interna do capital?

Foi por iniciativa de pensadores neomarxistas, como Henri Lefebvre, Jean Lojkine, Paul Boccara e Manuel Castells, que foi possível, fazer desde então, do ponto de vista da teoria 
urbana, uma verdadeira reviravolta no conceito do espaço citadino. Esses estudos urbanos tornaram-se referência obrigatória. Hoje, entretanto, cabe perguntar se as grandes transformações que vêm atravessando o território citadino reforçariam aquele debate francês para tratar do urbano. Pergunta-se se as categorias forjadas por esses pensadores seriam válidas para capturar as novas contradições que emergem do espaço urbano na contemporaneidade.

Este texto pretende apresentar e retomar esse debate colocando em evidência a contribuição de alguns desses pensadores para o estudo da dimensão social do território urbano na passagem para o século XXI. Interessa-nos demonstrar que o debate ocorrido na França há quarenta anos, sofreu inflexões que podem ser observadas, por exemplo, quando se recuperam os itinerários de alguns de seus principais intérpretes de primeira geração. Entendemos, entretanto, que é um equívoco teórico considerá-los, a priori, ultrapassados para capturar a polêmica socioespacial da atualidade. Pretendemos demonstrar que, apesar de tais inflexões e até mesmo enfoques e trajetórias intelectuais distintas, por vezes contraditórias, ainda são contribuições seminais para se pensar criticamente o espaço urbano na contemporaneidade.

Por hipótese, admitiremos que ainda são válidas algumas das categorias centrais utilizadas por essa tradição da Teoria Social Crítica francesa aplicadas à noção de território urbano, inclusive para chamar a atenção sobre os impactos das Novas Tecnologias de Informação e Comunicação (NTICs).

Pensando com esses autores, demonstramos que, em última instância, estamos no início de uma quadra histórica de metamorfose do espaço citadino que apenas começa a ser visualizada. 
Nossa perspectiva admite que esse processo de mutação trata-se, na verdade, de uma dinâmica de reconversão do espaço citadino. Essa reconversão pode ser demarcada pela passagem da conformação urbano-industrial do capital para o regime urbano-informacional de acumulação. Nossos argumentos apontam para a emergência de uma nova dimensão espacial-urbana que denominamos de Platô Informacional.

\section{A crítica urbana segundo a Escola Marxista Francesa}

A chamada nova sociologia urbana moderna nasce em solo francês com o texto seminal de Henri Lefebvre, ${ }^{1}$ Le droit à la ville (1968). Entretanto, o debate que nos interessa destacar tem sua origem na corrente marxista francesa do pensamento sociológico contemporâneo, notabilizada entre os anos de 1972-1982, quando teve como eixo temático a Questão Urbana. O objetivo é visualizar, pelo menos, duas linhas de estudos que se projetaram ao longo do tempo nesse campo teórico. São abordagens que alimentaram afinidades e diferenças, num primeiro momento, quando tematizaram a cidade capitalista sob a égide do Capitalismo Monopolista de Estado, cujos protagonistas, na atualidade, reorientam seus estudos para os impactos das NTICs. Embora sejam teorias díspares sob muitos aspectos, especialmente quando o assunto remete ao determinismo tecnológico, elas equiparamse por anunciarem a magnitude dos impactos sociais dessas novas tecnologias em relação à organização social urbana. São

1 Considerado um dos maiores intérpretes da obra marxiana na França, Henri Lefebvre foi responsável pela primeira crítica às concepções derivadas da Escola de Chicago. Apoiando-se no quadro do materialismo histórico, foi o fundador da Escola Marxista Francesa sobre o Urbano, de onde partiram os primeiros estudos de Manuel Castells e Jean Lojkine, entre outros. No conjunto das obras de Lefebvre, a cidade aparece subordinada à lógica da reprodução do capital, enquanto seu cenário e suporte. Cf. Lefebvre (1968, 1970a,1970b, 1999). 
perspectivas que, embora tenham se nutrido originalmente do marxismo, sustentam divergências tanto no primeiro quanto no segundo período de suas pesquisas, após a derrocada da antiga (URSS).

Os autores que sugiro como protagonistas do debate, são, de um lado, Manuel Castells ${ }^{2}$ e, de outro, Jean Lojkine ${ }^{3}$. Eles permanecem na cena acadêmica, promovendo pesquisas em diversas partes do mundo com o mesmo rigor científico que sempre norteou os seus trabalhos. Num primeiro momento, esses autores fizeram uso de categorias marxianas, para explicação da cidade na conjuntura do segundo pós-guerra, tais como: Capitalismo Monopolista de Estado, superestrutura/ infraestrutura, lutas de classe e outras; num segundo momento, suas perspectivas propõem caminhos interpretativos completamente diferentes a esses fundamentos marxistas. Procurei, desse percurso analítico diferenciado, extrair uma síntese com a qual pretendo abordar o objeto de estudo.

2 Manuel Castells nasceu na Espanha em 1942, emigrando para a França aos 20 anos. Em 1973, professor de Sociologia na Ecóle Pratique des Hautes Études (Sorbonne, Paris), dirige o Seminário de Sociologia Urbana, tendo a seu encargo o Seminário de Metodologia do Doutorado em Sociologia, sendo responsável pela equipe de pesquisa urbana do Centro de Estudos dos Movimentos Sociais dessa instituição. Doutor em Sociologia pela Universidade de Paris, em 1967, tem sido, sucessivamente, pesquisador do Laboratório de Sociologie Industrielle (Universidade de Paris), professor da Universidade de Paris - Nanterre, professor e consultor da UNESCO na Faculdade Latino-americana de Ciências Sociais (FLACSO) e também professor visitante do Centro de Desenvolvimento Urbano da Universidade Católica do Chile.

3 Jean Lojkine formou-se em Filosofia, em 1964, na Universidade Sorbonne. Doutorouse em 1976, com tese orientada por Alain Touraine, Le marxisme, l'État et la question urbaine (1977), publicada no Brasil com o título O Estado capitalista e a questão urbana (1981). Coordenou pesquisas no Centre National de Recherche Scientifique (CNRS). Vinculou-se ao Centro de Estudos sobre Movimentos Sociais, dirigido por Robert Castel. Seu objeto de estudo é a sociedade contemporânea, suas leis e pressões, de natureza social ou extra-social, às quais os atores de transformação social são remetidos, voluntária ou involuntariamente. A trajetória intelectual deste pesquisador é por ele mesmo visualizada fazendo relação de seus eixos sobre algumas temáticas, entre as quais: $O$ Estado e o urbano, consenso, consentimento e hegemonia, assalariado moderno e revolução informacional. 
Para esse percurso analítico, proponho antes duas rápidas remissões sobre essa perspectiva social crítica. Uma primeira diz respeito à originalidade da elaboração marxista sobre a temática urbana. Isso é importante uma vez que o pensamento iniciado por Marx e Engels foi resgatado nos anos 60 por autores hoje considerados clássicos para a discussão urbana (como, por exemplo, Henri Lefebvre) e que fecundaram as raízes do surgimento de linhas de pensamento sobre as quais iremos tratar mais adiante. Tais formulações estiveram relativamente alinhadas no marxismo clássico ou a um de seus intérpretes.

A segunda remissão - que se refere ao debate crítico sobre a perspectiva funcionalista manifestada pela Escola de Chicago e pelo Centro de Sociologia das Organizações ${ }^{4}$ - é sobre a leitura estruturalista da cidade que esteve presente no interior mesmo da corrente marxista. Essa fundamentação levou a leituras diferenciadas, seja do Estado, seja da própria cidade. Esse debate sobre o urbano, de base marxista, é importante por guardar uma estreita relação com o ambiente crítico dos anos 1960-1970. Dele pretendo extrair os traços que marcaram a diferença entre os dois autores selecionados, sobre suas hipóteses, para analisar as metamorfoses societais desta virada para o século XXI, sobretudo quando problematizam o uso das NTICs. Enquanto Lojkine propõe a hipótese da Revolução Informacional, que aponta para a emergência de potencialidades históricas para além dos limites da revolução industrial, Castells aposta na Sociedade da Informação centrada na nova morfologia das sociedades em virtude dos impactos da revolução tecnológica. Interessa-me nesse debate delimitar

\footnotetext{
4 A chamada Sociologia das Organizações Francesa foi implementada pela equipe de Michel Crozier a partir de 1964. Notabilizou-se por conduzir a defesa do modelo burocrático para a análise do Estado filiando-se à corrente funcionalista, sustentado pela hipótese de que a problemática da cidade se reduz à dinâmica das relações dos múltiplos grupos organizados (Lojkine, 1997, p. 51-78).
} 
o que aproxima ou distancia esses autores, tentando indicar seus desdobramentos sobre a problemática da espacialidade urbana em mutação.

Alocamos a origem do pensamento marxista sobre o urbano na primeira metade do século XIX, período em que se verificou a primeira onda de expansão industrial na Europa, que não demorou a se alastrar pelo mundo. Naquele período encontramos as críticas sociais pioneiras sobre a cidade em textos de Marx e Engels, quando ambos buscaram ultrapassar a dicotomia cidade-campo na descrição de seus fenômenos aparentes. O tratamento mais particularizado desse tema pode ser encontrado nas obras: Situação da classe operária na Inglaterra (1845) e Questão da habitação (1872), ambas de autoria de Engels.

Engels introduz uma análise crítica das condições socioeconômicas vividas pela classe trabalhadora na Inglaterra, propondo uma reflexão mais aprofundada sobre o fenômeno da cidade-industrial como uma das manifestações do capital. Trata-se, em sua maioria, de esboços e anotações sobre dados colhidos in loco, no chão das fábricas e nos bairros pobres das cidades e nas zonas rurais. No estudo dessa realidade, Engels fornece uma explicação alternativa à ideologia da descrição do crescimento demográfico e dos fluxos migratórios. Ele procura relacionar tais fenômenos ao que, de fato, estaria subjacente ao crescimento exponencial da aglomeração urbana na Europa, ou seja, o fundamento social oculto que nada mais era do que a emergência do novo modo de produção capitalista. ${ }^{5}$

\footnotetext{
${ }^{5}$ Segundo Hobsbawm (2005), as cidades cresciam com extraordinária rapidez: "Viena cresceu de mais de 400 mil em 1846 para 700 mil em 1880; Berlim de 378 mil (1849) para quase 1 milhão (1875); Paris de 1 para 1,9 milhão e Londres de 2,5 para 3,9 milhões (1851-81), embora esses números percam o brilho diante de alguns outros de além-mar: Chicago ou Melbourne".
} 
Em A ideologia alemã (1846) localizamos um dos elementos principais para a crítica marxista sobre o urbano. Segundo Marx e Engels, subjacente à separação cidade (operariado industrial) e campo (camponeses, bóias-frias) está a submissão do indivíduo à divisão social do trabalho. A cidade, que emergia, era dinamizada, sobretudo, pela atividade industrial. Enquanto o campo era reservado como espaço da produção agrícola, tendente ao isolamento. A cidade industrial é "obra da concentração da população, dos instrumentos de produção, do capital, do prazer e das necessidades" (Marx; Engels, 1998, p. 50). O crescimento vertiginoso das cidades industriais só poderia ser entendido se relacionado ao processo de concentração e rápido desenvolvimento dos padrões de inovação tecnológica (máquina a vapor) e dos novos métodos de organização da força de trabalho (divisão do trabalho). Essas mudanças afetavam simultaneamente a cidade e o campo.

A produção capitalista, em seu processo ampliado, valese da aparente, e ao mesmo tempo real, divisão cidade-campo, como uma unidade de contrários. Engels logo percebeu que o agricultor artesão, os pequenos proprietários ou arrendatários rurais que mantinham relações com a cidade, pouco a pouco, convertiam-se em operários urbanos, em substituição ao velho tear e à produção artesanal. Derivam desses primeiros estudos de Engels as noções de multidão solitária e alienação. Depreende-se dessa primeira abordagem marxiana que o capital é, de partida, urbano-industrial, que a população rural é arrastada pela lógica desse novo tipo de aglomeração urbana, essencialmente dinamizada pela ordem burguesa. O que está latente na desordem da cidade e do campo é, na verdade, a lógica da acumulação, concentração e reprodução da relação capital-trabalho, manifestada já no alvorecer do capitalismo: 
A burguesia não pode existir sem revolucionar permanentemente os instrumentos de produção e, por conseguinte, as relações de produção, e com isso todas as relações sociais [...] submeteu o campo ao domínio da cidade.[...] Criou urbes imensas; aumentou enormemente a população das cidades [...] A burguesia suprime cada vez mais o fracionamento dos meios de produção, da propriedade e da população. Aglomerou a população, centralizando os meios de produção e concentrando a propriedade nas mãos de uns poucos (Marx; Engels, 1973, p.109ss).

Enquanto Marx e Engels desenvolviam suas pesquisas nas cidades industriais inglesas, avaliando os efeitos da onda do "espectro revolucionário" que varreu a Europa nos idos do pós-1845, do outro lado do Atlântico, nos Estados Unidos da América, o ritmo de industrialização e urbanização induzia um clima de entusiasmo que animava as correntes migratórias de trabalhadores e intelectuais da Europa Central. Esse fluxo migratório em larga escala dirigia-se às cidades industriais nascentes naquele novo mundo.

Dentre essas cidades emergentes, alçadas ao progresso pela era do capitalismo concorrencial, destaca-se a nova Chicago, recém-reconstruída, ${ }^{6}$ que, aos poucos, tornou-se uma das pontes ídeo-políticas e culturais (com hegemonia conservadora) que ligará, sob o signo do progresso, aquela economia emergente ao velho mundo, ambos compassados pelo ritmo da revolução urbano-industrial. Na segunda metade do século XIX, migrantes rurais do Middle West chegaram em massa, bem como um número impressionante de imigrantes estrangeiros: alemães, escandinavos, irlandeses, italianos, poloneses, lituanos, checos, judeus. Em 1900, mais da metade

6 Chicago tornou-se um pólo de referência intelectual, de arte e cultura após o grande incêndio de 1871. "Nela foram construídos os primeiros arranha-céus dos Estados Unidos e desenvolveu-se um movimento arquitetônico modernista que também ficaria conhecido como Escola de Chicago" (Coulon, 1995, p. 12). 
da população de Chicago havia nascido fora da América. Chicago tornou-se uma cidade industrial, um centro comercial e uma próspera bolsa. $O$ capitalismo selvagem desenvolveuse e a cidade assistiu a tumultos (1886) e a grandes greves operárias (1894) (Coulon,1995, p.12).

Chicago, enquanto referência citadina norte-americana de arte, cultura e ciência, tinha um pólo irradiador: a Universidade de Chicago ou, como ficou mundialmente conhecida, "A Escola de Chicago". Fundada em 1890, graças à generosidade de John D. Rockefeller (que a financiou até o ano de 1910, totalizando a cifra de 45 milhões de dólares), essa Escola tornou-se uma referência intelectual mundial, muito em função do intercâmbio intelectual com a Europa, obtendo a transferência de importantes pensadores, especialmente os emigrados da Alemanha durante o final do século XIX. Mas, o período que vai consagrá-la no cenário sociológico acadêmico internacional ficará circunscrito aos anos de 1915 a 1940.

Segundo Coulon (1995, p. 123 ss), podem ser identificados dois momentos distintos da Escola: um primeiro, marcado pela ascensão de sua influência e produtividade científica que "se encerrou com a Segunda Guerra Mundial, no momento em que a sociologia americana se tornou mais quantitativa e mais diversa no plano teórico"; e um momento seguinte, caracterizado como uma espécie de "prolongamento", aquilo que se pode chamar de "segunda Escola de Chicago".

Mas, um outro fator não trabalhado por Coulon é justamente a interlocução crítica sobre os fundamentos dessa Escola, oferecida às ciências sociais pelos sociólogos marxistas franceses, que proporão uma fundamentação alternativa em relação aos estudos de Chicago para a explicação da cidade. Independentemente do período que se queira abordar a 
respeito da produção intelectual da Escola de Chicago, um traço demarca sua presença na discussão da problemática urbana: o caráter empírico de suas pesquisas e seus métodos "inovadores" de abordagem do campo. Fincadas as suas raízes no funcionalismo, a Escola de Chicago se pautava ou pelo Pragmatismo (isto é, na idéia de que a atividade humana deve ser considerada sob o ângulo de três dimensões, a saber: a biológica, a psicológica e a ética), ou pelo Interacionismo Simbólico (isto é, na idéia de que a vida social deva ser destacada a partir das significações de natureza simbólica advindas das relações sociais).

Partindo desses princípios, todo o desenvolvimento das pesquisas da Escola de Chicago vai ser demarcado pela produção, em larga escala, de uma espécie de "mosaico" bem diversificado de retratos das cidades daquele país, sobretudo da própria Chicago. Tais pesquisas se orientaram para tentar identificar fenômenos particulares que pudessem ser dissecados cientificamente de maneira a produzir resultados úteis para aplicações práticas, num discurso interpretativo adequado aos interesses, especialmente dos governantes locais, diante dos problemas sociais explosivos gerados nas cidades industrializadas.

Segundo essa Escola, as cidades deveriam ser entendidas enquanto objetos dessa ação interpretativa-interventivagovernamental. Outra característica fundamental originária de Chicago diz respeito ao seu método de apreensão do real. Pela primeira vez, na Sociologia Americana, são aplicados e desenvolvidos diversos sistemas originais de "pesquisa de campo", utilizando a combinação de fontes, tais como documentos pessoais, fontes primárias e secundárias, método até hoje utilizado em pesquisas quantitativas e qualitativas. 
Segundo Joas (1999), não desmerecendo a riqueza analítica que ainda possa ser resgatada do interacionismo simbólico, deve-se abstrair dessa escola de pensamento sua orientação exclusivamente empírica, que teve resultados restritos, considerando sua relevância em termos de poder de generalização da dinâmica social, especialmente urbana. No seu conjunto, sua obra está circunscrita aos temas relacionados aos migrantes na América, aspectos étnicos, imprensa, família, juventude, mobilidade feminina, controle da natalidade, divórcio, padrões demográficos, preconceitos, consciência de raça e assuntos teológicos. ${ }^{7}$

Propondo um balanço crítico em termos de seus elementos internos, Joas (1999) chama a atenção para dois âmbitos de expectativas não realizadas pela tradição do Pragmatismo e do Interacionismo Simbólico aplicados pela Escola de Chicago: um nível relativo à Teoria da Ação e um outro relativo à teoria da Ordem Social. No que diz respeito à Teoria da Ação, aponta para o problema da ascendência dos modelos utilitaristas que incidiram sobremaneira nas suas práticas de pesquisa, tornando-as reféns dos fins últimos, e, portanto, "incapazes" de explicar os fenômenos que não se enquadrassem nos critérios de racionalidade definidos a priori. Tais fenômenos, tomados como "anomalias", não eram tratados nem explicados: "eles produzem uma categoria residual de 'ação-racional' que não permite a reconstrução da diversidade fenomênica da ação".

Do ponto de vista marxista, a partir dos anos 1970 , sobretudo na Europa, surge um grupo de pesquisadores que vão enunciar os fundamentos críticos em relação à tradição

\footnotetext{
7 Assim como problemas de marginalidade, juizado de menores, novos modos de vida em hotel, sistemas de castigo, áreas de vício, suicídio, insanidade, seitas proibidas e religiosas, mídia, expressões coletivas e mudança cultural, fatores econômicos e instituições, bem como a companhia de trens de Chicago, a circulação de dinheiro no mercado, greves, além de estudos específicos sobre algumas comunidades.
} 
da Sociologia Urbana da Escola de Chicago. Dentre esses estudiosos do urbano destacam-se Castells e Lojkine. Esses autores admitem que existem limites ontológicos à produção intelectual da Escola estadunidense. Suas críticas vão se constituir na chamada Nova Sociologia Urbana.

Naquele período, as pesquisas urbanas realizadas pela ótica marxista e que tiveram em Lojkine e Castells alguns de seus maiores expoentes, na verdade, se referem a um grupo de pesquisadores bem mais amplo. Tais pesquisas foram permeadas por uma atmosfera política promovida pelos acontecimentos relacionados ao movimento estudantil francês também conhecido como "Maio de 68" (Amiot, 1986).

Esse movimento, como se sabe, obteve visibilidade e repercussão internacional e teve rebatimentos na Sociologia ocidental, sobretudo na discussão da segregação socioespacial nas cidades de capitalismo avançado. Desde então, essa Escola Marxista Francesa deu início a um programa de estudos sobre o urbano sendo tomada como referência para um olhar histórico-estrutural sobre a cidade. Esta corrente de pensamento sobre o urbano difundiu-se por diferentes centros de pesquisa de outros países, e seus estudos tornaram-se referência básica para as pesquisas latino-americanas sobre a problemática urbana no período da Guerra Fria, ganhando hegemonia no Brasil (Ramos, 1994b), especialmente após o período da "redemocratização". Manoel Castells, entre outros, produziu A questão urbana (1972 [1983]) e Jean Lojkine ganhou visibilidade junto ao público brasileiro, especialmente, com a publicação de $O$ Estado capitalista e a questão urbana (1977 [1981]).

8 Os colchetes indicam a primeira edição em língua portuguesa no Brasil. 
No pós-1968, a perspectiva marxista francesa caracterizou-se, entre outros aspectos, por abrir uma frente de crítica aos fundamentos do pensamento sociológico predominante na época, especialmente à Escola de Chicago, por entender que esta vertente estaria reduzindo o tratamento da Questão Urbana aos aspectos exteriores do modo de produção capitalista, particulares, escamoteando, consciente e inconscientemente, a lógica do capital subjacente à dinâmica da composição urbano-industrial que havia sido anteriormente denunciada pelos clássicos Marx e Engels. Os franceses contemporâneos foram além destes clássicos do século XIX e atualizaram as fontes originais, tendo como síntese um novo paradigma para tratamento da problemática urbana do século $X X$. Este novo conceito de fundamentação teórica sobre o urbano se articulava a uma interpretação de um estágio de desenvolvimento do capitalismo identificado como Capitalismo Monopolista de Estado, que assumia características distintas às da fase anterior do capitalismo, no tempo de Marx, o Capitalismo Concorrencial.

Nem Castells, nem Lojkine se satisfaziam com a crítica reduzida e preliminar do pensamento original marxiano. Era necessário descer às particularidades urbanas do capitalismo do Pós-Guerra. Mesmo partindo do pressuposto de que o pensamento marxista era condição necessária para fazer essa trajetória investigativa, esse mesmo pensamento era insuficiente na leitura das novas determinações do capital - apenas esboçadas na crise do capital, enunciada entre os anos 1960 e 1970 -, manifestadas na problemática urbana contemporânea.

No ambiente político que precedeu o governo Mitterrand (iniciado em 1981), movidos pelo Programa Comum de Governo, pesquisadores de diferentes partidos de esquerda 
e centro-esquerda se debruçaram sobre a leitura dos dilemas urbanos para formulação de estratégias de intervenção (Ramos, 1994b, p. 478).

Sustentando-se no marxismo para o tratamento da cidade, esses pesquisadores tentavam superar a nova "ideologia do urbano". Essa ideologização estaria centrada, sobretudo, na perspectiva dos estudos etnográficos na base de uma aplicação do Interacionismo Simbólico. Esses estudos estariam servindo de amálgama sociológico com um viés filosófico do pensamento inspirado no "pragmatismo norteamericano", cujo celeiro era a Escola de Chicago, cidade-sede apresentada, mapeada e dissecada. Pensavam o contrário: aquela cidade, como qualquer outra contemporânea, não era inteligível pela doutrina fetichizada das relações sociais naturalizadoras da ocupação espacial urbana. Por meio da crítica ao Estado capitalista, propunham uma leitura da cidade com base em Poulantzas (Castells), ou em Boccara, com sua teoria do Capitalismo Monopolista de Estado (Lojkine, 1997). Diferentes centros de pesquisa urbana surgiram e/ou se expandiram, sendo os mais importantes o Laboratório de Movimentos Sociais, vinculado à Escola de Altos Estudos em Ciências Sociais (EHESS), e o Centro de Sociologia Urbana, do CNRS, ${ }^{9}$ prevalecentes até hoje (Amiot, 1986, p. 125)

Diferentes autores publicaram suas obras abordando temáticas diversas contidas no urbano como produto da lógica capitalista, tendo em comum uma crítica rigorosa à mistificação do urbano como ente a-histórico, espaço físico passivo, alheio aos conflitos de classe, ou objeto unilateral da ação dos agentes (entendidos como pessoas, sistemas e/ou organizações),

9 Centro nacional de pesquisa científica, de função similar à do CNPq, no Brasil, distinguindo-se deste por ter quadro próprio de pesquisadores e centros de pesquisa. 
sem uma correspondência analítica com a dinâmica estrutural capitalista.

Essa crítica marxista sobre as múltiplas expressões da problemática urbana procurou demonstrar que nem o espaço, nem as organizações e nem os agentes estariam isentos da disputa econômica, política e ideológica da luta de classes não podendo se desprender, de forma autônoma, da lógica estrutural do capital, na linha do que já tinha sido denunciado pelos primeiros marxistas.

Segundo esses críticos europeus, quanto mais o capitalismo avançava no desenvolvimento das forças produtivas e das condições gerais da produção (em meio à conjuntura da Guerra Fria), tanto mais eram confirmadas suas assertivas. O Estado Capitalista, na contemporaneidade, vinha assumindo uma nova feição, entendida por eles como alterações explicadas pelo ingresso em um novo estágio do monopólio: o Capitalismo Monopolista de Estado. Para Castells, o modo de produção capitalista na atualidade caracteriza-se por alguns traços fundamentais:

1) crescimento sem precedente da massa da mais-valia, mas, ao mesmo tempo, papel central da luta contra a baixa tendencial da taxa de lucro, derivado do aumento cada vez mais acelerado da composição orgânica do capital; 2) desenvolvimento acelerado, embora desigual e contraditório, das forças produtivas; 3 ) desenvolvimento desigual e contraditório, mas sempre ascendente, da luta de classes [...] revela-se, não um capitalismo estagnado, mas um capitalismo que se desenvolve de modo contraditório, acelerado e ininterrupto, atravessando novas fases no interior do estágio monopolista [...] As contradições assim suscitadas colocam sempre os termos de uma alternativa histórica, mas o aspecto principal da contradição resulta sempre de um processo histórico determinado - dependendo da luta de classe e de sua expressão política (Castells, 1983, p. 570). 
Partindo desse pressuposto, o autor de $A$ questão urbana (1983), vai demonstrar que o espaço, por exemplo, enquanto grandeza física não diz nada, e, em si mesmo, não é útil para explicar o fenômeno da aglomeração urbana, mas sim enquanto suporte das relações sociais fundamentais do modo de produção que precisaria ser entendido segundo as condições historicamente determinadas. Somente sob esse ponto de vista é que o espaço urbano passaria a ser útil ao estudo da cidade capitalista, uma vez que estaria desnudo das roupagens ideológicas dominantes que o transfiguram e impedem que seja visualizado na sua condição social de mediação estratégica e fundamental à reprodução das condições imediatas de produção.

As diferenças de classes são impressas e cristalizadas no corpo citadino, e, em última instância, vão ser moldadas pela dinâmica estrutural do modo de produção capitalista. Esse processo, segundo essa visão, (re)condiciona-se na contemporaneidade à medida que são incorporadas novas determinações à necessidade inerente ao capital de se reproduzir:

Por um lado uma organização do espaço específica para cada um dos elementos do processo de produção imediata (força de trabalho e reprodução da força de trabalho, meios de produção e reprodução dos meios de produção); por outro, uma organização do espaço específica à gestão do processo de trabalho; enfim, o espaço do processo de circulação do capital. Coloca-se o fato de que, ao menos no que diz respeito ao estágio monopolista do modo de produção capitalista, os dois últimos processos, referentes à gestão e à circulação do capital, caracterizam-se por sua deslocalização, sua movimentação em escala mundial. Trata-se da eliminação tendencial do espaço enquanto fonte de especificidade (Castells, 1983, p. 555).

A crítica castellsiana vai incidir sobre a tradição sociológica norte-americana, porque rejeita por completo a perspectiva 
interacionista simbólica por considerá-la insuficiente para explicar a lógica do capital aplicada ao estudo das aglomerações urbanas. Segundo Castells, o problema daquelas abordagens sociológicas reside no fato de admitirem, por pressuposto, aspectos questionáveis, por exemplo, da ecologia urbana, que naturalizam as relações sociais de vizinhança:

Assim, por ex., se se parte de uma análise culturalista do urbano, esforçar-se-á em estabelecer e comparar "estilos de vida" diferentes segundo as formas de espaço e em revelar neles os vínculos de causalidade subjacentes. Se se parte da contradição entre "cidade" e "campo", estabelecer-se-ão as características destes dois termos e mostrar-se-á em seguida o efeito próprio destas características geográficas e econômicas sobre as relações sociais que daí resultam. Se se permanece numa análise de produção do espaço, escolher-se-á tal ou tal processo econômico ou político e mostrar-se-á o resultado ao qual eles conduzem no que concerne à forma espacial [...] Se se parte da análise que temos efetuado, centrar-se-á, antes de mais nada, sobre a análise dos meios coletivos de consumo, estudando-os de modo diferencial segundo o tipo da força de trabalho que é preciso reproduzir e as contradições de classe que nele se exprimem de maneira específica (Castells, 1983, p. 563).

Esse autor vai insistir também na crítica ao método empiricista, considerando-o superficial. Em contrapartida, ele oferece seu método, batizado de "aproximações sucessivas", que se caracteriza pela formulação de análises parciais da realidade urbana para, em seguida, voltar à teoria no mesmo momento em que se obtêm informações sobre a organização em questão numa sociedade determinada.

O ponto central da sua proposição recai no uso de categorias marxianas, mediação sobre as quais o autor irá assentar sua formulação explicativa do universo das relações sociais urbanas. Destacamos a categoria Condições Gerais 
de Reprodução da Força de Trabalho como a que merecerá maior destaque. Além da crítica elaborada por Lojkine à sua concepção de urbano (1981, p. 79-106), baseada na crítica à leitura de Estado de Poulantzas, ressaltamos que Castells pensa a cidade apenas como espaço de reprodução, apoiada na noção de consumo final.

Essa leitura, embora avance em termos do pensamento urbano americano, é também parcial, uma vez que, para Lojkine, Castells não se refere ao processo de extração da mais-valia, deixando, portanto, de fora de suas análises, como diz o próprio autor, o consumo produtivo. Decorrente desses distanciamentos da própria teoria social exposta por Marx (1998b) em O Capital, entende-se que as diferenças em relação à proposição lojkineana de crítica à ideologia do urbano se evidenciam ainda mais quando Castells apresenta, no posfácio de 1975 , sua resposta às primeiras críticas à $1^{\text {a }}$ edição de A questão urbana, livro publicado em 1972.

Temos recordado a distinção clássica de Marx entre consumo coletivo (que concorre para a reprodução dos meios de produção) e consumo individual (que concorre para a reprodução da força de trabalho) e consumo de luxo (consumo individual que excede as necessidades históricamente determinadas de reprodução da força de trabalho). [...] o consumo produtivo [...] nós o excluímos momentaneamente do campo de análise a fim de simplificar o trabalho, já bastante complexo [grifo nosso] (Castells, 1983, p. 574).

Antes da crítica à concepção de Estado de Poulantzas (1968 [1977]), e procurando localizar o seu desvio de interpretação, Lojkine (1981p. 51-79), em O Estado capitalista e a questão urbana, faz uma crítica ao funcionalismo aplicado à Sociologia Urbana, sendo seus interlocutores a Escola de Chicago e, principalmente, a Sociologia das Organizações na 
França. ${ }^{10}$ Por outro lado, Lojkine quer denunciar o parentesco existente entre a abordagem funcionalista norte-americana e uma certa leitura estruturalista do pensamento de Marx. Essa sua crítica desemboca na leitura althusseriana de $O$ Capital (Althusser, 1965), difundida no Brasil no período da ditadura, apropriada por Castells, pela mão de Poulantzas, e aplicada em $A$ questão urbana.

Duas conseqüências de primeira ordem decorrem dessa "reificação" mecanicista de Marx: 1. O conceito hegeliano de contradição interna é eliminado, o que impede os estruturalistas de conceitualizarem a mudança. 2. O indivíduo, o ator social, fica reduzido a 'suporte de uma função econômica', o que impede que seja explicado o papel dos indivíduos na História, sobretudo o fenômeno de 'tomada de consciência' revolucionária e de luta de classes (Lojkine, 1997, p. 86).

Desse ponto de vista, Lojkine vai entender a proposição de Castells (décadas de 1970-1980, portanto, Castells I) ${ }^{11}$ como um desvio interpretativo de Marx aplicado ao estudo do urbano. Segundo seu ponto de vista, aquele autor, pela via que adota, vê-se diante da impossibilidade de propor uma teoria da mudança (Lojkine, 1997 p.79 e ss).

Não considerar a urbanização como elemento-chave das relações de produção, reduzi-la ao domínio do 'consumo', do 'não-trabalho', opor reprodução da força de trabalho - pela urbanização - a dispêndio do trabalho vivo - na empresa - é,

\footnotetext{
${ }^{10}$ Com base em suas pesquisas, Lojkine desenvolve um conjunto de concepções em sua tese de doutorado (1977). Na $2^{\mathrm{a}}$ edição brasileira (1997) consta um importante prefácio em que o autor faz uma espécie de "balanço crítico", não só de sua trajetória, mas do pensamento marxista subjacente à obra, em face da derrocada da antiga URSS, sobretudo em sua hipótese da revolução informacional.

${ }^{11}$ Para efeito didático, tratarei do debate entre Castells e Lojkine em dois momentos, e, para distinguir esses momentos, utilizo os codinomes Castells I (referente a interpretações de sua obra A questão urbana) e Castells II, mais maduro, quando publica sua trilogia sobre a Era da Informação (1999-2000). Da mesma forma, trato de Lojkine I (O Estado capitalista e a questão urbana) e Lojkine II (A revolução informacional).
} 
ao contrário, retomar um dos temas dominantes da ideologia burguesa, segundo o qual só é 'produtiva' a atividade de produção da mais-valia. Ora, as formas contraditórias do desenvolvimento urbano, do modo como são refletidas e acentuadas pela política estatal, são justamente a revelação do caráter ultrapassado da maneira capitalista de medir a rentabilidade social através apenas da acumulação do trabalho morto (Lojkine, 1997, p. 144).

Lojkine se apóia diretamente em O Capital, usando como categorias-chave aquelas explicitadas por Marx (1998, p.126141) em sua análise de classes sociais: processo imediato de produção, reprodução do capital, reprodução ampliada das classes sociais e desenvolvimento do modo de produção (sua transformação histórica e dissolução).

Para pensar o processo de reprodução ampliada do capital, o autor faz uso da categoria Condições Gerais da Produção. Essa categoria é operada tendo em vista a análise das dinâmicas urbanas associadas aos meios de comunicação e transporte. Esse tipo de aplicação categorial vai se revelar de relevância crucial para se entender os desdobramentos futuros nas pesquisas dos dois pensadores. Enquanto Lojkine retomará esses elementos no tratamento da revolução informacional, Castells tenderá a abster-se de qualquer resgate categorial marxiano para o tratamento da sociedade da informação.

Em que pesem essas diferenças dentro do campo marxista, esses autores vão identificar, por caminhos diferentes, a emergência e a predominância do setor serviços como o elemento-chave para se entender a particularidade do Urbano nas condições do chamado Capitalismo Monopolista de Estado.

Neste sentido, além do caráter crítico que os autores nutrem em relação à tradição positivista, ao empirismo 
aplicado ao estudo das cidades na perspectiva funcional e da planificação tecnocrática, eles vão destacar também a questão da distribuição desigual dos equipamentos de consumo coletivo e dos serviços públicos como um dos elementos-chave para a releitura econômico-social da cidade como estratégia contraideológica para explicitar o caráter de luta de classes das cidades, das políticas urbanas e do Estado, entendendo-os como determinações advindas da dinâmica do capital.

Segundo Castells I, essa nova sociologia urbana é apresentada do ponto de vista da esfera da reprodução da força do trabalho. Sua análise vai operar uma crítica sistemática das principais contribuições ao estudo da urbanização no intuito de produzir uma reconstrução do pensamento sobre a problemática urbana com base na teoria marxista, codificada a partir de sua primeira leitura althusseriana, ${ }^{12}$ objetivando validar uma série de novos instrumentos de pesquisas empíricas sobre políticas urbanas.

Esse caminho de abordagem crítica vai conduzir o autor para a identificação do fundamento para explicar a composição da cidade nas relações sociais de luta social pela concentração e distribuição dos meios de consumo coletivo (vitais à reprodução da força do trabalho). Entendida como uma cotidianeidade de relações sociais circunscritas nesse ambiente não-fabril, isto é, no âmbito residencial, mas que tem no Estado o principal agente definidor das políticas urbanas cristalizadoras dos processos de segregação socioespacial.

Apesar das diferenças de fundamentação e conceituação do Estado entre os dois pesquisadores da Escola Marxista Francesa, em Lojkine o Estado capitalista também vai ser

12 No posfácio de 1975, Castells vai retificar essa leitura considerada por ele como formalista. 
identificado como o principal responsável pela distribuição social e espacial dos equipamentos urbanos.

Fundamentando-se criticamente em Gramsci, Lojkine vai propor um Estado ampliado, ao mesmo tempo agente de coerção e de realização de consenso na ocupação do espaço urbano. Neste sentido, a política urbana será interpretada como momento essencial e constitutivo da reprodução do capital na sua fase monopolista.

O Estado, portanto, será entendido como expressão, simultaneamente, da tensão política, no sentido de prover o atendimento das necessidades de reprodução ampliada do capital, (admitindo-se inclusive, os conflitos entre frações das classes dominantes), mas, sem com isso, deixar de refletir na materialidade espacial da cidade as contradições e as lutas de classe geradas pela segregação social.

Resumindo, no período de 1972 a 1982, Castells (I) e Lojkine (I) vão concordar, até certo ponto, que, ao se considerar o estágio de desenvolvimento do capitalismo avançado, o caráter histórico-estrutural da urbanidade estará associado à radicalização das condições estruturais de heterogeneização dos espaços citadinos, portanto, a cidade é por esses autores entendida como forma de agregação humana no espaço da urbanidade que, em ultima instância, é a condição social mais compatível com as exigências do capital avançado.

A urbanidade será então apresentada não mais como objeto do planejamento ou como ambiente passivo da coleta de dados empíricos, mas como condição social indispensável à reprodução ampliada do Capitalismo Monopolista de Estado. Este fato coloca para o pesquisador contemporâneo o desafio de pensar o urbano na perspectiva da luta de classes manifesta nas condições de acesso desigual aos equipamentos de 
consumo coletivo (Castells) e/ou na reprodução ampliada das Condições Gerais da Produção (Lojkine).

Desse modo, a urbanidade passa a ser pensada pela originalidade da Escola Marxista Francesa a partir das lutas sociais e do papel do Estado na produção e distribuição desses equipamentos e serviços. Assim, a cidade vai ser reconstituída como sendo a materialização da expressão da luta social contra o capital e cristalizada no processo de segregação socioespacial urbana dinamizado pela lógica do capital.

Em 1999, portanto mais de vinte e cinco anos após a publicação de A questão urbana (1972), é lançado no Brasil o primeiro volume da trilogia de $A$ era da informação, com o título A sociedade em rede (1996 [1999]). Considerada por muitos como a obra-prima de Castells, para nós, curiosamente, esse lançamento editorial vai reacender a polêmica com Lojkine, que, em 1995, publicara no Brasil o livro A revolução informacional. Essas referências literárias de cariz prospectivo sobre as transformações contemporâneas vão demarcar duas clivagens teóricas: uma primeira que diz respeito à nova relação que cada um vai estabelecer com os fundamentos do marxismo, e a outra que se refere ao enfoque que cada um toma em relação ao impacto social das NTICs.

Por outro lado, tais coincidências não vão apagar as diferenças de interpretação manifestadas no período anterior, quando ambos abordaram a questão urbana. Ao contrário, a hipótese é que as primeiras diferenças atravessarão os dois períodos, condicionando as análises prospectivas que estão contidas nas duas últimas publicações.

Enquanto Castells se omite de fazer qualquer prognóstico em termos de potencialidades políticas de caráter emancipatório em relação ao capital a partir das transformações societais 
enunciadas na trilogia $A$ era da informação - visto que ele abandona por completo a perspectiva da luta de classes na contemporaneidade -, em $A$ revolução informacional essa perspectiva libertária ainda está no centro das preocupações de Lojkine.

Essa divergência de análise histórico-estrutural da contemporaneidade não se reduz a uma irrelevante diferença interpretativa, em que pese o consenso que há entre esses autores sobre os gigantescos impactos globais advindos da Revolução Tecnológica ou dos usos e desusos das NTICs. Ao contrário, são fundamentos distintos que alimentam a emergência de um novo debate que atravessará gerações, tal como sucedeu nos anos 1970 com os impactos sociais da Revolução Industrial e que, no caso do primeiro debate (Castells I e Lojkine I), manifestara-se no enquadramento da questão urbana.

Enquanto para Lojkine II estaríamos vivenciando uma oportunidade fundamentalmente política de ultrapassagem das mazelas de uma sociedade de classes a partir do anúncio da potencialidade de uma nova civilização pós-mercantil, um momento caracterizado como um processo de mutação societal só comparável à invenção da ferramenta e da escrita, para Castells II a expectativa da Era da Informação representaria

a promessa [...] de uma capacidade produtiva jamais vista, mediante o poder da mente. Penso, logo produzo. Com isso, teremos tempo disponível para fazer experiências com a espiritualidade e oportunidade de harmonização com a natureza sem sacrificar o bem-estar material dos filhos. O sonho do Iluminismo está ao alcance (Castells, 1999c, p. 437).

Castells, em A era da informação: economia, sociedade e cultura, afirma que a base material da sociedade está sendo remodelada pela revolução tecnológica concentrada 
nas tecnologias da informação de tal maneira que estaríamos assistindo à emergência de uma nova forma de relação entre a economia, o Estado e a sociedade. Portanto, a explicação para essa transformação estaria associada a dois processos históricos da maior relevância e que se interpenetram: o colapso do estatismo soviético e a reestruturação do capitalismo.

Segundo Castells, se o colapso da antiga URSS, por um lado, trouxe o enfraquecimento do movimento comunista internacional frente ao desafio de enfrentamento ao capitalismo, por outro, livrou o pensamento marxista da atração fatal do marxismo-leninismo. Do ponto de vista da reestruturação do capitalismo, ele ressalta os seguintes fenômenos como sendo da maior relevância:

Maior flexibilidade de gerenciamento; descentralização das empresas e sua organização em redes tanto internamente quanto em suas relações com outras empresas; considerável fortalecimento do papel do capital vis-à-vis o trabalho, com o declínio concomitante da influência dos movimentos de trabalhadores; individualização e diversificação cada vez maior das relações de trabalho; incorporação maciça das mulheres na força de trabalho remunerada, geralmente em condições discriminatórias; intervenção estatal para desregular os mercados de forma seletiva e desfazer o Estado do Bem-Estar Social com diferentes intensidades e orientações, dependendo da natureza das forças e instituições políticas de cada sociedade; aumento da concorrência econômica global em um contexto de progressiva diferenciação dos cenários geográficos e culturais para a acumulação e a gestão de capital (Castells, 1999c, p. 437).

Segundo esse autor, tais transformações estariam conduzindo a sociedade a um processo de interdependência global marcadamente orientado pela nova dinâmica dos mercados financeiros, promovendo a emergência de uma nova geopolítica. 
Essa nova configuração espaço-temporal - a globalização - teria como características a concentração de comando segundo a lógica dos fluxos de capitais na região do Pacífico Asiático, que estaria tensionando também a necessidade do projeto de unificação da Europa; a formação de uma economia regional na América do Norte; e a diversificação, depois desintegração, do ex-Terceiro Mundo.

Enfim, sob os efeitos de uma metarrede estaríamos sendo condicionados por essa territorialidade global imaterial, marcadamente influenciada por uma nova lógica e um padrão de relacionamento econômico entre as nações, remodelando as antigas formas de dominação e desigualdade não apenas entre o Norte e o Sul, mas entre os segmentos e territórios dinâmicos das sociedades.

Para lidar com essa realidade mutante, Castells propõe três categorias: o informacionalismo, a sociedade em rede e a emergência de novas identidades culturais, com as quais procurará desvendar as mudanças societais na contemporaneidade. Encontraremos na exposição dessas categorias elementos para um debate profícuo com Lojkine em $A$ revolução informacional (1995), visto que tais autores se, por um lado, vão convergir nas suas argumentações no que diz respeito à relevância social de um tratamento sério sobre a questão tecnológica na contemporaneidade, por outro lado, vão se distanciar radicalmente nos fundamentos para a compreensão dessa dinâmica.

Em Castells, o surgimento do informacionalismo é apresentado como um novo modo de desenvolvimento surgido a partir da década de 80 em oposição ao estatismo, ao industrialismo. O informacionalismo é definido como "a nova base material, tecnológica, da atividade econômica e da organização social' (Castells, 1999a, p. 31-36). 
Para sustentar sua hipótese da emergência do informacionalismo, Castells afirma que as sociedades são organizadas em processos estruturados por relações historicamente determinadas de produção, experiência e poder. Se admitirmos que o edifício da teoria social crítica possa ser sumariamente apresentado como sustentado por três pilares fundamentais, a saber: uma teoria do valor-trabalho, uma teoria da revolução e a primazia da dialética materialista como o método capaz de interpretar a dinâmica social concreta, podemos então estabelecer, segundo esse balizamento, os termos do debate entre os autores escolhidos nesta segunda fase de sua produção intelectual. Esperamos com isso, poder sistematizar uma síntese útil ao quadro analítico.

Diferentemente do que ocorrera em $A$ questão urbana (1972), o Castells II, de $A$ sociedade em rede (1999), irá se desprender de qualquer referência mais direta e rigorosa em relação às categorias originais de Marx e isso fica evidente, por exemplo, ao tratar do conceito de produção, categoria essa por ele desenvolvida como sendo uma das três premissas com as quais ele vai definir o novo modo de desenvolvimento - o informacionalismo.

Nos termos da teoria crítica clássica da economia política, a produção não pode ser dissociada das relações de produção e vista a partir de um núcleo fundamental, o conceito marxiano de mais-valia. E sabe-se também que, na contemporaneidade os neomarxistas têm dado muita ênfase a esse fundamento (especialmente no que tange à mais-valia relativa) ao se tratar da problemática da produtividade em face do processo de reestruturação produtiva, automação, pós-fordismo, toyotismo etc.

É uma perspectiva que procura dar relevância às novas problemáticas advindas da relação entre trabalho vivo e 
trabalho morto, ou seja, os novos padrões de acumulação e expropriação do trabalho não-pago diante dos desafios efetuados para se pensar a questão da maquinaria nos termos de Marx e revista segundo as novas contradições do trabalho informacional. Sob o impacto das redes, o processo produtivo, segundo Castells (1999), centra-se na discussão em torno da questão da produtividade e da competividade, que serão consideradas como os principais processos da economia informacional/global. Ele aloca a origem da produtividade essencialmente na inovação, na competitividade e na flexibilidade das relações de produção:

Portanto, empresas, regiões, países, unidades econômicas de todas as espécies preparam suas relações de produção para maximizar a inovação e a flexibilidade. A tecnologia da informação e a capacidade cultural de utilizá-la são fundamentais no desempenho da nova função da produção. Além disso, um novo tipo de organização e administração, com vistas à adaptabilidade e coordenação simultâneas, torna-se a base do sistema operacional mais efetivo, exemplificado pelo que rotulei de a empresa em rede (Castells, 1999c, p. 417).

Esse novo processo produtivo se desdobrará, segundo o autor, no surgimento de uma mão-de-obra auto-programável, apresentada a partir da oposição em relação à mão-de-obra genérica. Enquanto a primeira é composta por um trabalhador que é instruído de tal maneira que atingiu níveis educacionais mais altos, ou seja, com conhecimentos incorporados e informação, a mão-de-obra genérica tende a não possuir recursos de reprogramação e a limitar-se a receber e executar sinais, sendo formada por trabalhadores reduzidos a terminais humanos, podendo ser substituídos por máquinas.

Em Castells, a perspectiva da revolução está associada à radicalidade com que emergem as transformações societais 
advindas das conquistas no campo da tecnologia da informação que subordinam as dimensões econômicas, sociais e culturais da sociedade no século XXI. Em seu ponto de vista, estamos assistindo a um intervalo cuja característica é a transformação da cultura material pelos mecanismos de um novo paradigma tecnológico que se organiza em torno da tecnologia da informação.

A revolução da tecnologia, a reestruturação da economia e a crítica da cultura convergiram para uma redefinição histórica das relações de poder e experiência em que se baseia a sociedade (Castells, 1999c, p. 416).

Distanciando-se da tradição da teoria social crítica de Marx, segundo a qual a perspectiva da revolução tem no mundo do trabalho seu ambiente fundamental e campo de batalha, cujo templo de observação e manifestação fundamental é a grande indústria e o sujeito histórico adequado é o proletariado, Castells, de $A$ sociedade em rede, vê a revolução como um processo que se efetiva externamente à vontade de uma classe em particular.

Trata-se de uma ruptura de padrão tecnológico com características absolutamente originais em relação à revolução da máquina a vapor e da energia elétrica, com a particularidade de ser mais rápida e mais efetiva do que aquelas revoluções de padrão tecnológico-industrial. A revolução tecnológica atual é promovida cada vez mais pelos impulsos de ciência que tendem a condicionar todas as demais dimensões das atividades humanas. Desse processo podem surgir novas identidades pró-ativas e não simplesmente ações reativas em face dessas transformações tecnológicas capazes de edificarem projetos societais.

Como exemplo desse tipo de novo sujeito político em rede, Castells procura destacar dois tipos de movimentos 
sociais: o feminismo e o ambientalismo. Neste sentido, a categoria da revolução rompe com a tradição fundamental da teoria social crítica de ter no mundo do trabalho a fonte das contradições de luta social de confrontação de classes antagônicas. A perspectiva castelliana de revolução depende muito mais da cultura do que do trabalho produtivo ou do confronto capital/trabalho:

Meu ponto de partida, e não estou sozinho nesta conjetura, é que no final do século XX estamos vivendo um desses raros intervalos na história. Um intervalo cuja característica é a transformação da 'cultura material' pelos mecanismos de um novo paradigma tecnológico que se organiza em torno da tecnologia da informação (Castells, 1999a, p. 49).

Para Castells, a revolução da tecnologia da informação acentuará seu potencial transformador no século $X X I$, quando se dará a conclusão da infovia global, a expansão da telecomunicação móvel. Todos esses processos são impulsionados pela capacidade da informática de descentralizar e difundir o poder da informação, concretizando a promessa da multimídia e aumentando a alegria da comunicação interativa. Além disso, será o século do pleno progresso da revolução genética.

Castells II, ao adotar as premissas de "experiência" e "poder" para tratar do informacionalismo como modo de desenvolvimento econômico-social, omite-se quanto a qualquer referência à luta de classes numa perspectiva de superação do capital como modo de produção ou como categoria explicativa válida em termos de uma (re)construção de identidade fundada na cultura da solidariedade de classe dos que vivem do trabalho. Nem mesmo a categoria Consciência de Classe é resgatada na sua formulação original, tendo em vista a construção de uma identidade social baseada na luta social contra o capital. 
A noção marxista que distingue classe em si de classe para si não é retomada, em A era da informação, para identificar o potencial emancipatório da "sociedade da informação", uma vez que as pesquisas de Castells apontam para uma tendência à fragmentação e à individualização do trabalho segundo um processo de crescente enfraquecimento do sentimento de pertencimento a uma classe formada a partir do trabalho, tal como ocorrera na grande indústria.

Além disso, o método da dialética marxiana, que propõe a apreensão da dinâmica social a partir da identificação da dimensão de totalidade entendida como oposição entre unidade de contrários, não é aplicado, visto que, no caso do informacionalismo, por exemplo, desenvolve-se uma argumentação sem fazer uso de uma unidade de contrários historicamente referenciada. Neste sentido, o informacionalismo, mesmo quando apresentado em oposição ao industrialismo, parece estar centrado historicamente em si mesmo. Assim, Castells propõe como tendência histórica, que as sociedades vão ser organizadas segundo a morfologia organizacional que ele designará como redes.

Castells esclarece que a sociedade em rede não é um processo que se desenvolve de maneira idêntica em todo o planeta, ao contrário, ele ocorre de maneira combinada e desigual segundo as especificidades históricas e materiais de cada país. No entanto, essa diferença particular não invalida sua tese geral de que uma das características fundamentais do diferencial dessa revolução em relação às demais revoluções tecnológicas é que ela ocorre simultaneamente em todo o globo numa fração de tempo muito curto (duas décadas aproximadamente).

Desse ponto de vista, as identidades culturais vão ser (re)constituídas na contemporaneidade em face da emergência 
desse novo padrão de identidade que, se por um lado, é prenhe de potencialidades de liberação de criatividade, comunicação, trabalho e produção, por outro é expressão de um novo sistema de dominação, erguido a partir de uma nova base informacional das redes computadorizadas que conectam sistemas opressivos, tais como mercados voláteis, empresas transnacionais e Estados autocráticos.

Enfim, essa é a plataforma fundamental do exercício da hegemonia exercida pela lógica financeira e também pelos grupos organizadores da violência, opressão, crimes e todo tipo de barbarismos. Como desdobramento dessa avalanche opressora/potencializadora sobre as individualidades, Castells aplica uma tipologia de novas identidades culturais: identidades legitimadoras, identidades de resistência, identidades de projeto. Sem entrarmos no mérito de cada uma dessas abordagens, é importante ressaltar que é nas identidades de projeto que Castells vai alocar um tipo específico de movimentos sociais considerados pró-ativos, isto é, aqueles que, utilizando-se de qualquer tipo de material cultural ao seu alcance, constróem uma nova identidade capaz de redefinir sua posição na sociedade e, ao fazê-lo, de buscar a transformação de toda a estrutura social. Esse é o caso do feminismo, por exemplo, que abandona as trincheiras de resistência da identidade $e$ dos direitos da mulher para fazer frente ao patriarcalismo, à família patriarcal e, assim, a toda a estrutura de produção, reprodução, sexualidade e personalidade sobre a qual as sociedades historicamente se estabeleceram.

O que me parece evidente em Castells II, de A era da informação (1999), é que a atividade dos movimentos sociais é enfocada segundo um ponto de vista culturalista do potencial da sociedade em rede, isto é, uma perspectiva que hipertrofia a condição identitária cultural da ação coletiva emergente na 
sociedade em rede, ao mesmo tempo em que tende a atrofiar a condição histórico-material que está subjacente a esse processo. Talvez isso ocorra porque ele comungue da tese daqueles que supõem um esvaziamento bastante irreversível das energias utópicas (Habermas, 1987), advindas do mundo do trabalho, pelo menos, tal como se manifestaram no século $\mathrm{XX}:{ }^{13}$

A economia informacional, como acontece com todas as formas de produção historicamente distintas, é caracterizada por cultura e instituições específicas. [...] a diversidade de contextos culturais de onde surge e em que evolui a economia informacional não impede a existência de uma matriz comum de formas de organização nos processos produtivos e de consumo e distribuição. [...] afirmo, em companhia de um crescente número de estudiosos, que culturas manifestam-se fundamentalmente por meio de sua inserção nas instituições e organizações (Castells, 1999a, p. 173).

Desse modo, a categoria Revolução vai ser tomada a partir de uma ação de identidades individualizadas ou coletivizadas que se erguem contra os novos padrões de dominação assumindo a forma de "identidades autônomas em construção" em substituição à noção marxiana, pelo que nos parece dizer Castells, admitindo-se a extinção das identidades de classe tal como foram forjadas no contexto da revolução industrial.

O que caracteriza os movimentos sociais e projetos culturais construídos com base em identidades na Era da Informação é que eles não se originam dentro das instituições da sociedade civil. [...] Na era industrial, os movimentos de trabalhadores travavam luta ferrenha contra o capital. O capital e o trabalho, contudo, compartilhavam os objetivos e valores da industrialização, produtividade e progresso material. [...] Na Era da Informação, a

${ }^{13}$ Sobre essa tese do esvaziamento das "energias utópicas" advindas do mundo do trabalho, confira Habermas (1987). 
principal lógica das redes globais predominantes é tão difusa e penetrante que o único modo de se livrar de seu domínio parece ser ficar fora delas e reconstruir o significado com base em um sistema de valores e crenças inteiramente distinto. Esse é o caso das comunas de identidade de resistência por mim identificadas (Castells, 1999c, p. 411-439).

Lojkine, por outro lado, em $A$ revolução informacional (1995), também vai se ocupar, como ponto de partida, das transformações contemporâneas associadas à revolução tecnológica. Mas seu enfoque teórico é bastante diferente do de Castells II, em que houve um enquadramento teórico da categoria do informacionalismo como um novo modo de desenvolvimento circunscrito aos conceitos de revolução tecnológica, sociedade da informação ou tecnologias da informação.

Em Lojkine os fundamentos da teoria social crítica de Marx e Engels centrados na teoria do valor, na perspectiva da revolução e no método dialético vão ser retomados, revistos e até ampliados diante dos novos desafios colocados, sobretudo, pelas mutações ocorridas no mundo do trabalho advindas das aplicações tecnológicas da informação nos processos produtivos.

Para Lojkine, a hipótese da revolução informacional remete necessariamente às categorias marxianas de Condições Gerais da Produção, Forças Produtivas e Relações de Produção. É verdade que, no seu entender, os fenômenos contemporâneos invisíveis à conjuntura histórica dos clássicos remetem a uma revisão crítica de tais categorias, explorando suas impropriedades, adaptações e superações.

Segundo Lojkine, o enfoque teórico a ser tomado para a abordagem dos novos limites e potencialidades sociopolíticas, econômicas e emancipatórias das NTICs não descarta 
aqueles fundamentos; pelo contrário, há casos em que é preciso reconhecer a força de sua fecundidade analítica desde que se estabeleça não um diálogo dogmático, mas crítico e profícuo.

O que há em comum entre Lojkine e Castells, é que os dois autores, além da trajetória intelectual que desloca o eixo de suas pesquisas do urbano para o informacional, encontram-se na crítica tanto ao viés apocalíptico quanto ao integrado, muito difundido no debate entre tecnofóbicos e no reforço da perspectiva positiva e otimista no enquadramento das potencialidades políticas, econômicas, sociais e culturais advindas do impacto ontológico das mudanças em curso. Isso não os exime de terem que pagar o preço de críticas vindas tanto daqueles que tendem a se colocar no marco do ceticismo da potência revolucionária de tais mudanças quanto dos que acham desnecessário e contraproducente qualquer referência aos fundamentos da teoria crítica ou mesmo do projeto humano iniciado com o movimento iluminista do século XVIII. ${ }^{14}$

\section{A condição social das redes}

Embora a forma de organização social em redes possa ser verificada em outros tempos, Castells (1999, p.497) demonstra que o "novo paradigma da tecnologia da informação fornece a base material para sua expansão penetrante em toda a estrutura social'. Por esse raciocínio - da presença ou não da rede -, estar ou não conectado a ela, distingue uma condição sócio-histórica de poder, para além das capacidades dos indivíduos em particular. É por isso que, segundo o autor,

${ }^{14}$ Para uma crítica ceticista da perspectiva desses autores, confira Gorender (1999, p.197-219). Para os fundamentos de uma crítica pós-moderna, ver Lyotard (1979). 
o poder dos fluxos torna-se mais importante que os fluxos do poder.

Diferentemente da perspectiva sociológica relacional, Castells destaca a primazia da morfologia social concreta sobre a ação social. A nova sociedade em formação, diz Castells, tende a assumir a conformação de redes. Para o autor, rede é um conjunto de nós interconectados. O que venha a ser um "nó" vai depender do tipo de rede concreta que se pretende estudar. ${ }^{15}$ A primazia da morfologia da rede em relação aos atributos de cada nó em particular faz com que estar ou não conectado seja mais preponderante do que, por exemplo, a distância (física, social, econômica, política, cultural) de cada nó que se pretenda estudar na sua particularidade. Isto ocorre porque os fluxos informacionais operam à velocidade da luz. Daí porque, a expressão "tempo real" só tenha sido compreensível neste momento histórico pós-revolução tecnológica. Neste sentido, o tempo passou a ser exercido socialmente segundo a lógica das redes informacionais que, ao desprezarem as distâncias físicas, fazem tais distâncias estarem submetidas à lógica das dinâmicas virtuais.

Por serem estruturas abertas, na visão de Castells (1999), as redes são capazes de se expandir de forma ilimitada, integrando novos "nós" desde que compartilhem os mesmos códigos de comunicação. Isso não quer dizer que não haja tensões internas e externas que venham a comprometer a condição de "nó" ou mesmo de desagregação da rede como um todo.

${ }^{15}$ Em nosso estudo de doutoramento consideramos, por hipótese, que essa perspectiva castelliana seria útil para definir uma dimensão de análise para se estudar o processo e expansão de sujeitos-redes potenciais no espaço urbano recriado pelas redes informacionais denominado de Platô Informacional do Distrito Federal. Em nosso estudo, cada organização filiada à CUT/DF revelar-se-ia no Platô Informacional como um "nó" de uma rede urbano-informacional mais ampla e em processo expansão, tendo em vista o seu projeto político. 
Castells chama a atenção ainda para o fato de que as redes tendem a se constituir em instrumentos apropriados para a economia capitalista. Este modo de produção se utiliza da inovação para agregar valor advindo do trabalho, esteja ele onde estiver, porém ainda mantém os traços fundamentais de tentar subordinar essa força do trabalho a uma lógica de concentração de poder e capital. Por outro lado, a morfologia das redes também está afetando drasticamente as relações de poder à medida que os fluxos informacionais, conectados, por exemplo, pelo sistema financeiro, rompem as barreiras nacionais de proteção ao crédito, transnacionalizando suas vulnerabilidades econômico-sociais pela ação remota de grupos monopolistas que assumem o controle de mercados, influenciam processos políticos das nações e desorganizam sociedades.

A convergência da evolução social e das tecnologias da informação criou uma nova base material para desempenho de atividades em toda a estrutura social. Essa base material construída em redes define os processos sociais predominantes, conseqüentemente dando forma à própria estrutura social (Castells, 1999a, p.498).

Em outro campo sociológico, o da Sociologia Social Crítica, observa-se também o reconhecimento de que efetivamente há algo de substantivo a ser tratado no uso do conceito de redes. Alguns poucos teóricos marxistas começam a observar que nesta categoria há uma força explicativa importante para a análise dos processos de mutação do modo de produção capitalista. No centro dessa abordagem está a categoria marxiana de forças produtivas, que passa a ser revisitada em função das alterações verificadas no interior dos processos produtivos. $O$ pano de fundo dessa reflexão marxista está no reconhecimento de que, diferentemente do que Marx pôde verificar em seu tempo, atualmente tem havido 
um definhamento do papel do proletariado em relação ao crescimento dos assalariados do setor serviços.

Nessa perspectiva teórica, a idéia de redes tem sido destacada como uma conformação decorrente do processo de reconfiguração da divisão social e técnica do trabalho, refletindo, em última instância, a dinâmica do desenvolvimento das forças produtivas mais adequada ao chamado capitalismo "flexibilizado", mas que, na verdade, é a expressão dos novos impasses típicos da contradição entre as velhas relações de produção industriais e os imperativos da revolução informacional. Neste sentido, pensadores como Jean Lojkine e Paul Boccara identificam nos processos de conexões e interconexões das redes de informação a emergência de um fenômeno muito maior: a ultrapassagem da condição social industrial de organização do trabalho pelo desenvolvimento das forças produtivas típicas de uma outra ordem - a da revolução informacional.

Por esse ponto de vista, o conceito de redes ganha uma outra dimensão analítica em que estaria associado, para além dos fenômenos aparentes ou exteriores, ao modo de produção. Ao contrário, tornar-se-ia elemento constitutivo e constituinte das relações sociais que estão em processo de mutação no âmbito das instituições e organizações sociais que antes separavam as interações no tempo e no espaço do mundo da cultura e da política do mundo do trabalho.

Lojkine, em palestra realizada no Brasil em 1997, ${ }^{16}$ vê na emergência das redes informacionais um fenômeno típico das

${ }^{16}$ Por ocasião do I Colóquio Brasileiro de Serviço Social e Políticas Urbanas, realizado em Angra dos Reis. Desde então, Jean Lojkine participa como consultor internacional do Núcleo Brasileiro de Pesquisa sobre Poder Local, Políticas Urbanas e Serviço Social (Locuss) tendo contribuído também com os seminários promovidos por esse Núcleo de Pesquisas em Brasília (1999), Belém (2002) e no Rio de Janeiro (2003). 
transformações advindas do processo de ultrapassagem do paradigma industrial diante das mudanças na organização do trabalho e do desempenho das forças produtivas em mutação. Para Lojkine (1997, p. 4), quanto mais se avança nas gerações informáticas, com os sistemas especializados, mais a presença humana e a interatividade se tornam fundamentais.

Boccara (1984), por seu turno, distingue a revolução industrial da informacional em seus fundamentos. A primeira poderia ser caracterizada pela adoção: 1) da substituição da mão dos trabalhadores manipulando o instrumento pelo uso das máquinas-ferramentas; 2) do aperfeiçoamento constante dos motores promovendo a substituição das máquinas a vapor por dínamos elétricos e depois pelos motores a explosão; e, 3) de normas de reorientação das tarefas a serem desempenhadas pelos trabalhadores cada vez mais especializados de modo a cobrirem com o trabalho vivo os buracos deixados pelo trabalho morto, isto é, da mecanização. A hipótese da revolução informacional, do ponto de vista estritamente tecnológico, se caracterizaria não mais pela substituição da mão manipulando o instrumento, mas pela substituição de certas funções do cérebro pelos computadores e pela automação (Boccara, 1984, p.2).

Na perspectiva da Escola Marxista Francesa, ${ }^{17}$ seria necessário ir além da leitura evolucionista e linear que caracterizaria o "sistema técnico ocidental", segundo a qual, no plano histórico, a transformação tecnológica dar-se-ia em estágios lineares do mais grosseiro para o mais fino. Ao contrário, para estes marxistas franceses, as redes tornaram-se elemento intrínseco e, por isso, estariam no coração mesmo

17 Daqui para diante, quando me referir à Escola Marxista Francesa estarei tratando do pensamento de Lojkine e Boccara. 
de todas as alterações substantivas do sistema tecnológico. No cerne desse processo de mutação histórico-estrutural, se encontraria a transformação do instrumento de trabalho da sua tradicional condição material para a incorporação de tecnologias informacionais. Essa máquina-ferramenta-informacional tende a estar cada vez mais potencializada e habilitada a efetivar a substituição de algumas funções cerebrais, elevando o papel e o grau de importância da circulação das informações estratégicas humanas no interior dos processos ampliados de produção e reprodução do capital.

Se, no período industrial, os serviços se encontravam de forma dissociada das atividades produtivas, hoje se colocam imbricados com o processo de produção tornando-se indispensáveis ao desenvolvimento do capital no sentido da apropriação do trabalho imaterial que se caracteriza pelo uso intensivo das trocas de informações. ${ }^{18}$ Para Lojkine (1997), ao pretenderem se apoderar dos mercados dos serviços urbanos, os grandes capitalistas procuram desagregar a população usuária dos serviços em grupos de consumidores cada vez mais segmentados, tentando controlar os mecanismos de acesso às redes de equipamentos e serviços coletivos urbanos. Por outro lado, o trabalho tende a se apropriar de práticas autônomas de acesso a circuitos informacionais com potencial para questionar tanto o processo de controle da produção, quanto os sentidos públicos do sistema produtivo como um

${ }^{18}$ A Escola Marxista Francesa não é a única que retoma o pensamento de Marx como ponto de partida para tratar da polêmica a respeito do trabalho imaterial. O pensamento seminal do pensador clássico alemão a esse respeito é também recomposto mesmo por aqueles que abandonaram a centralidade do trabalho. Cf., a esse respeito, Gorz (1982). Os franceses se caracterizam por guardarem a fidedignidade e originalidade do pensamento de Marx centrando a discussão contemporânea da categoria Forças Produtivas. Em Marx essa discussão tem origem nos Manuscritos econômicos e filosóficos, se aprofunda em $A$ ldeologia alemã, mas ganha fecundidade histórica em O Capital, pois não se dissocia da noção de cooperação. Cf. Marx $(1978,1998)$ e Marx e Engels (1998). 
todo, à medida que podem acessar, à revelia do controle $\mathrm{e}$ dos interesses da rentabilidade do capital, a publicidade antes inatingível no regime industrial. Isto quer dizer que o trabalhador informacional tem, hoje, o poder incontrolável de investir sobre os espaços públicos estratégicos.

Na proposição de Lojkine, a Revolução Informacional conduz a novos impasses entre o velho e o novo regime de produtividade. As redes de equipamentos e serviços coletivos proporcionam efeitos úteis ao processo produtivo como um todo, mas, sob o efeito da revolução informacional, ao serem privatizados sob o critério tradicional, ao contrário do que pretendem as corporações capitalistas, só geram círculos viciosos. Neste sentido, Lojkine (1997, p. 2), chama a atenção para o fato de que a revolução informacional não altera somente as formas de produzir e de trabalhar; ela coloca em questão, igualmente, a própria concepção de eficácia econômica, tal como foi fundada sobre a base da grande indústria capitalista.

É desse impasse que emerge a necessidade de se repensar as redes de equipamentos e serviços coletivos (transporte, educação, saúde, cultura, comunicação, entretenimento e segurança pública) dentro de um outro critério de eficácia societal em que não estejam mais submetidos à lógica da rentabilidade clássica do capital. ${ }^{19}$ É a superação dessa visão fetichizada das redes informacionais que permitirá o avanço democrático da sociedade informacional e que os sujetos-rede emergentes efetivem o controle do público, isto é, a efetivação do projeto político a ser articulado por múltiplos atores sociais em coalizão. Essa perspectiva nada tem a ver

\footnotetext{
${ }^{19}$ A eficiência capitalista clássica se mede pela rentabilidade, ou seja, a obtenção do lucro máximo a partir da minimização dos custos (input) e pela maximização da renda (output); busca-se conservar positivo o saldo do balancete input/output (Simon, 1983).
} 
com o padrão estatizante ou comercial de controle das redes de difusão da informação. Estes se tornaram padrões de rede reféns do autoritarismo no controle dos fluxos informacionais afeitos ao desperdício e à corrupção:

$\mathrm{Na}$ medida em que a revolução informacional atinge, hoje, todos os setores das atividades humanas (econômicas, sociais, domésticas), torna-se necessário imaginar outros critérios, ao mesmo tempo mercantis, monetários, mas também não mercantis, que sejam capazes de medir de maneira mais satisfatória, não mais produtos, mas efeitos úteis, 'valores de uso coletivos', difundidos no espaço e no tempo (Lojkine,1997b, p. 6).

A crítica de Lojkine chama a atenção para o fato de que o potencial das redes de equipamentos e serviços, em face da revolução informacional, está no seu "valor de uso coletivo", isto é, dirigido a uma necessidade social que só pode ser satisfeita coletivamente (Lojkine, 1999b). As redes tenderiam, então, a interferir no processo produtivo, gerando efeitos úteis, mas, por outro lado, tais efeitos não se subordinariam à lógica da rentabilidade tal como foi empregada pelo modelo industrial clássico.

Neste sentido, o autor propõe o uso de critérios de eficácia societal por serem mais apropriados a esse momento de mutação histórica. Os efeitos úteis dessas redes de equipamentos e serviços orientados por critérios de eficácia societal, isto é, para além do capital, sustentariam uma reorientação do conceito de redes na contemporaneidade, não mais como uma metáfora, norma ou método, mas como uma condição sócio-histórica inerente e indissociável da emergência da Revolução Informacional, que não se reduz aos seus efeitos tecnológicos imediatos, mas, ao contrário, é ampliada na sua potencialidade histórica quando apropriada politicamente dentro do escopo de luta capital/trabalho. 
A hipótese teórico-analítica da Revolução Informacional, tal como a tratamos, dá subsídios para se dizer que, hoje, há um papel pró-ativo do território exercido muito mais pelos acréscimos de ciência e técnica apropriados politicamente, do que pela disposição passiva dos chamados "equipamentos urbanos" ou elementos físicos e naturais. $O$ acesso a tais acréscimos de ciência e de técnica sobre o território será visto aqui não como um processo apartado das lutas sociais, mas ao contrário, "são seus produtores e possuidores - empresas, Estado e sociedade - que vão decidir sobre seus usos" (Santos; Silveira, 2001, p. 94).

Em O Estado capitalista e a questão urbana, Lojkine já assinalava as primeiras premissas do que viria a ser sua nova percepção sobre o urbano para além da perspectiva da Revolução Industrial:

Essa abordagem do urbano como condição geral da produção capitalista permitiu-me apreender uma das originalidades da revolução informacional com respeito à revolução industrial, a saber: o papel crucial dos serviços urbanos no crescimento da produtividade global. Ao mesmo tempo, essa abordagem inseria o processo de socialização urbana numa tríplice contradição entre seu valor de uso coletivo e sua apropriação privada (Lojkine, 1997, p. 16).

Em A revolução informacional, Lojkine (1995) vai indicar por onde passa a metamorfose urbana diante do novo paradigma informacional. Segundo esse autor, o padrão de acumulação que combinava socialmente os homens no espaço nacional e internacional mediante o predomínio das atividades industriais estava centrado, principalmente, no papel dinâmico da fábrica metalúrgica promotora de um processo de separação do proletariado industrial dos prestadores de serviços, ao mesmo tempo em que favorecia uma segregação socioespacial. Já no 
momento atual, em que ocorre a passagem para a Revolução Informacional, há uma tendência para uma integração urbana de funções via redes telemáticas promotoras da cooperação entre serviços-indústrias centrada no papel dinâmico da metatrônica, da cooperação entre professores e pesquisadores e assalariados da indústria (Lojkine, 1995 p.79).

\section{O Platô Informacional}

Denominamos de Platô Informacional a plataforma que dá suporte a todas as relações urbanas informacionais e que tende a converter e fazer convergir todas as antigas bases de sustentação das relações sociais urbanas. Tornase, portanto, o processo de subsunção do espaço urbano material à nova condição imaterial das redes informacionais citadinas, sobretudo através das redes telemáticas. Esta nova condição urbana sucede o padrão urbano-industrial, tornandose a nova condição urbano-informacional. É uma base que dá sustentação às relações sociais que se realizam através de circuitos de comunicações reconvertendo o espaço-tempo das trocas informacionais, promovendo a constituição de redes sociais de cooperação produtiva e política. Essa base de apoio tende a assumir uma conformação digitalizada à medida que sua configuração coincide com a supremacia da Internet como expressão maior desse processo histórico.

O Platô Informacional torna-se, portanto, a categoria adequada ao estudo do espaço citadino por possibilitar capturar as dinâmicas de incorporação tanto material quanto imaterial que tendem a assumir a morfologia de uma rede cujos "nós" seriam constituídos dos equipamentos e serviços coletivos conectados às vias telemáticas. Nessa nova paisagem territorial permite-se vislumbrar as múltiplas dimensões e 
potencialidades políticas daquilo que é chamado batalha da opinião pública (Lojkine, 1999).

A configuração do Platô Informacional agrega, simultaneamente, tanto as redes de equipamentos coletivos e serviços que operam a territorialidade material, isto é, a tecnoesfera - que é, segundo Milton Santos (2001), o meio técnico-ciêntífico informacional -, quanto as redes desenvolvidas para a manutenção das dinâmicas imateriais desse território. Desse modo, o conceito de Platô Informacional permite monitorar os processos de interação das redes de cooperação produtiva e das redes de cooperação política.

Para efeito de uma análise empírica, um Platô Informacional pode ser configurado a partir dos seguintes conjunto de indicadores:

Grupo 1 - Infra-estrutura - irrigação, barragens, portos, aeroportos, ferrovias, rodovias, hidrovias, instalações ligadas à energia elétrica, refinarias e dutos, bases materiais das telecomunicações, além de semoventes e insumos ao solo. Tal como Milton Santos define o meio técnico-científico informacional (Santos; Silveira, 2001, p. 55).

Grupo 2 - Internet - quiosques de Internet, telecentros, páginas na Internet, provedores de acesso à Internet, cybercafés, escolas de informática, provedores de correio eletrônico.

Grupo 3 - Política - câmaras legislativas, sindicatos, associações de moradores, ONGs, partidos políticos, igrejas/templos, centros acadêmicos, empresas e residências. 
Grupo 4 - Equipamentos - equipamentos coletivos investidos de autoridade pública, tais como: ensino em geral, agências dos correios, bibliotecas, postos de informação etc.

Grupo 5 - Co-presença - salas de cinema, salas de teatro, auditórios, espaços de arte, contros desportivos, clubes, bares, praças públicas, parques, zoológicos, comércio em geral.

Grupo 6 - Mídia - bancas de revistas, outdoors, jornais, emissoras de rádio, editoras, editorias, emissoras de TV aberta, emissoras de TV por assinatura, canais públicos e/ou comunitários, produtoras locais, agências de publicidade.

Para a configuração analítica de um determinado recorte do Platô Informacional poder-se-ia integrar tantos espaços de manifestação e expressão social quantos se queira utilizar, de sorte que se possa abstrair deles os enlaces de publicização, ou seja, conexões entre nós das redes informacionais onde se processam os fluxos informacionais baseados em relacionamentos do tipo fonte-audiência.

Os fluxos informacionais são volumes de informações que se estabelecem nesses enlaces entre, pelo menos, dois nós de uma mesma rede. Os fluxos podem estabelecer sentidos de direcionamento informacional que obedecem a uma lógica dialógica, ora como fonte de informação, ora como audiência. O conjunto dos enlaces informacionais de uma rede forma circuitos que, no seu todo, criam uma rede social constituinte do Platô Informacional de uma determinada área geográfica.

O Platô Informacional constitui-se, dessa forma, na categoria analítica auxiliar que se refere, em detalhe, ao 
conjunto dos nós de uma determinada rede social que pode congregar diversos circuitos informacionais. O Platô torna-se o locus, por excelência, dos fluxos informacionais. Esses fluxos são permanentemente tensionados por circuitos informacionais em sentido contrário e que disputam a hegemonia das audiências estabelecidas.

Cada enlace de publicização realiza seus fluxos informacionais num determinado espaço virtual ou presencial, onde se opera a comunicação dialógica, isto é, uma conversação que articula a locução de, pelo menos, dois sujeitos: um Sujeito-fonte (proponente do discurso político) que é, na verdade, um reeditor publicizador da informação estratégica em relação com outro Sujeito-de-audiência (outro reeditor potencial interessado em acessar a informação publicizada pelo primeiro). ${ }^{20}$ Essa relação social realizada pelos "nós de publicização", ao conectar-se com outros nós, multiplica seu efeito-rede potencializando a espacialidade material e imaterial do território reconstituindo o espaço que efetivamente ocupa no Platô Informacional. Esse processo é, ao meu ver, a nova condição social de rede que tende a caracterizar a territorialidade urbana contemporânea.

Com o incremento da revolução informacional, o Platô Informacional torna-se o espaço privilegiado da política e da produção imaterial. É, ao mesmo tempo, concreto e virtual. ${ }^{21}$

\footnotetext{
${ }^{20}$ Isso não quer dizer que essa relação esteja restrita a um único sentido, pelo contrário, admite-se que para ser um indicador do Platô Informacional as relações de comunicação possam ser processadas num sentido de reciprocidade de publicação de sentidos. Por este ponto de vista, o ator-audiência é, ao mesmo tempo, ainda que potencialmente, um autor-fonte e vice-versa.

${ }^{21}$ Estou usando aqui a unidade de contrários do "concreto/virtual" como elemento da potência teleológica do ser social. Diferentemente do sentido do senso-comum, que tende a fazer a oposição entre o real-virtual, entendendo o primeiro termo como tudo aquilo que se refere às relações em presença física e o segundo termo como tudo o que se passa em cenários computacionais, inclusive aquele criado pela Inteligência Artificial.
} 
Neste sentido, a idéia de Platô Informacional dialoga com Henri Lefebvre (1999b, p.16) quando esse autor se ocupa em estudar um "objeto virtual, a sociedade urbana, ou seja, um objeto possível, do qual teremos que mostrar o nascimento e o desenvolvimento relacionando-o a um processo e a uma práxis (uma ação prática)."

No Platô Informacional as relações sociais são realizadas mediante o exercício da comunicação no sentido freireano, quer dizer, cria-se um espaço que favorece e é favorecido pala prática da comunicação em sua vocação libertária:

comunicação [é] a co-participação dos sujeitos no ato de pensar [...] implica uma reciprocidade que não pode ser rompida [...] comunicação é diálogo na medida em que não é transferência de saber, mas um encontro de sujeitos interlocutores que buscam a significação dos significados (Freire, apud Lima, 2001 p. 55).

Sob esse prisma freireano, o Platô, enquanto uma condição material e imaterial da comunicação social, possibilita ultrapassar as abordagens teóricas unilaterais que tendem a fazer uso de dicotomias de tipo: público-privado, emissor-receptor etc. Essas construções lógico-formais reduzem a capacidade potencial-dialógica de reedição dos sentidos das mensagens por múltiplos fluxos e argumentos, independentemente e/ou alternativamente às tentativas de manipulação de sentido.

Em suma: Platô Informacional refere-se ao espaço contínuo e descontínuo, territorializado e desterritorializado formado pela conexão dos nós de publicização das redes de equipamentos e serviços. É uma plataforma que congrega as relações sociais produtivas e políticas, locais e globais, onde os fluxos de informação são integrados via circuitos informacionais que podem construir consensos ou conflitos em busca da hegemonia das opiniões das audiências em jogo. 
A Revolução Informacional tende a promover a digitalização do Platô Informacional, tornando-o uma macrorede formada por micro-redes digitais onde se expandem as capacidades de esses nós reeditarem mensagens, sob critérios diferenciados (por vezes antagônicos) em relação ao acesso a fontes de informação, conteúdo e audiências. Todo esse processo repercute direta e indiretamente na conformação da opinião pública.

\section{Conclusão}

O primeiro ponto, em termos de uma conclusão provisória do que tentamos expor nesse artigo, talvez seja responder a seguinte pergunta: O que o Platô Informacional tem a ver com a critica francesa acerca do espaço urbano?

Nesse sentido, o texto traçou um itinerário sobre a reconstituição do pensamento marxista francês admitindo, por hipótese, que esses estudiosos laçaram as primeiras luzes (ainda na passagem da primeira para a segunda metade do século passado) sobre a lógica do capital na sua ambição de abstrair novos sentidos espaciais da moderna urbanidade. Tais abordagens são imprescindíveis para uma perspectiva de análise crítica, competente e não fetichizada, do espaço urbano em processo de reconversão na contemporaneidade conforme nos indicam os fundamentos da atual teoria da Revolução Informacional, proposta pelos remanescentes dessa Escola ainda em atividade.

Platô Informacional constitui, portanto, o novo território onde se amalgamam e conectam os nós de publicização efetivados tanto pelas redes de cooperação produtiva quanto pelas redes de cooperação política. É o local material e imaterial 
por onde se constituem os circuitos informacionais estratégicos capazes de reescrever a geografia tradicional urbana. É o espaço por excelência que tende a exercer influência decisiva nos processos de batalha da opinião pública.

\section{Referências bibliográficas}

ALTHUSSER, L. Pour lire Le Capital. Paris: Maspero 1965.

. Análise crítica da teoria marxista. Rio de Janeiro: Zahar, 1967.

AMIOT, Michel. Contre L'Etat, les sociologies: éléments pour une histoire de la sociologie urbaine en France: 1900-1980. Paris: Ed. de l'École des Heutes Étudies en Sciences Sociales, 1986.

BOCCARA, P. Sur la revolution informationnelle. La Penseé, n. 241, set. 1984.

CASTELLS, Manuel. Problemas de investigación en sociología urbana. México: Ed. Século XXI, 1971.

. City, class and power. Londres: Macmilan. 1978.

. Cidade, democracia e socialismo. Rio de Janeiro: Paz e Terra, 1980.

. A questão urbana. Rio de Janeiro: Paz e Terra, 1983.

. A sociedade em rede. São Paulo: Paz e Terra, 1999a. (A era da informação: economia, sociedade e cultura, v. 1).

. O poder da identidade. São Paulo: Paz e Terra, 1999b. (A era da informação: economia, sociedade e cultura, v. 2).

. Fim do milênio. São Paulo: Paz e Terra, 1999c. (A era da informação: economia, sociedade e cultura, v. 3).

- A galáxia da internet: reflexões sobre a internet, os negócios e a sociedade. Rio de Jeneiro: Jorge Zahar Ed, 2003.

COCCO, G.; SILVA (Org.). Cidades e portos, os espaços da globalização. Rio de Janeiro: DP\&A, 1999. 
COULON, Alain. A Escola de Chicago. Campinas: Papirus, 1995.

ENGELS, F. A situação da classe trabalhadora na Inglaterra. Lisboa: Presença, 1975. 1979.

A questão da habitação. Belo Horizonte: Aldeia Global,

GORZ, André. Adeus ao proletariado: para além do socialismo. Rio de Janeiro: Forense Universitária, 1982.

HABERMAS, Jürgen. Teoria de la acción comunicativa. Madrid: Taurus, 1987.

HARVEY, David. A condição pós-moderna. São Paulo: Loyola, 1994. 2005.

A produção capitalista do espaço. São Paulo: Annablume,

JOAS, Hans. Interacionismo simbólico. In: GIDDENS, A.; TURNER, J.

Teoria social hoje. São Paulo: UNESP, 1999.

LEFEBVRE, Henri. A cidade do capital. Rio de Janeiro: DP\&A, 1999.

[Traduzido do original datado de 1972].

. Du rural à l'urbain. Paris: Antropos, 1970a.

. La révolution urbaine. Paris: Antropos, 1970b.

. Le droit à la ville. Paris: Antropos, 1968.

LIMA, V. A. de. Mídia: teoria e política. São Paulo: Editora Perseu Abramo, 2001.

LOJKINE, J. O Estado capitalista e a questão urbana. São Paulo, Martins Fontes, 1981. [2. ed. publicada em 1997].

. Projet d'Observatoire Européen des Expérimentations SocioÉconomiques dans l'Enterprise. Paris, 1997b. [Não publicado].

. O tabu da gestão: a cultura sindical entre contestação e proposição. Rio de Janeiro: DP\&A, 1999.

. A classe operária em mutações. Belo Horizonte: Oficina dos Livros, 1990.

. A revolução informacional. São Pauloa: Cortez, 1995.

. Entreprise et societé. Paris: PUF, 1999.

. Le nouveau salariat du capitalisme informationnel. 1999. [Não publicado]. 
LOJKINE, J. Alternativas em face da mundialização: a instituição municipal, mediação entre empresa e sociedade. In: RAMOS, Rauta (Coord.). Mutações societais e políticas urbanas. Rio de Janeiro: DP\&A, 2002.

. Estratégias políticas e sindicais em face da mundialização e da reestruturação produtiva. Revista Praia Vermelha: Estudos de Política e Teoria Social, Rio de Janeiro, n. 2, 1999. Disponível em: www.cfch.ufrj.br/datalocuss.

MARX, K. Elementos fundamentales para la crítica de la economia política (Grundrisse, 1857-1858), 2. México: Siglo Veitiuno, 1997. p. 12-36.

. Manuscritos econômico-filosóficos e outros textos escolhidos. São Paulo: Abril Cultural, 1978.

. O Capital: livro 1. Rio de Janeiro: Civilização Brasileira, 1998.

MARX; ENGELS. A ideologia alemã. São Paulo: Martins Fontes, 1998.

. O Manifesto do Partido Comunista. In: MARX; ENGELS. Obras escolhidas. São Paulo: Alfa-Omega, 1973. v. 1.

PAVIANI, Aldo (Org.) Brasília: gestão urbana, conflitos e cidadania. Brasília: UnB, 1998.

. Brasília, ideologia e realidade: espaço urbano em questão. São Paulo: Projeto, 1985.

. Brasília: a metrópole em crise: ensaios sobre a urbanização. Brasília: Ed. UnB, 1991.

. Brasília: moradia e exclusão. Brasília: Ed. UnB, 1996.

PAVIANI, Aldo; FERREIRA, Ignez C. B. Cidades-Satélites: organização do espaço urbano no Distrito Federal. In: SEMINÁRIO DE ESTUDOS DOS PROBLEMAS URBANOS DE BRASÍLIA. Anais... Brasília: Senado Federal, 1974. p. 41-50.

PAVIANI, Aldo; GOUVEIA, Luiz A. de Campos (Orgs.). Brasília: controvérsias ambientais. Brasília: Ed. UnB, 2002.

POULANTZAS, Nicos. Poder politico e classes sociais. São Paulo: Martins Fontes, 1977.

RAMOS, Rauta (Org.). Metamorfoses sociais e políticas urbanas. Rio de Janeiro: DP\&A, 2003. 
RAMOS, Rauta (Org.). Política e teoria: programa comum e movimentos sociais urbanos: as condições sócio-políticas do debate na França. Tese (doutorado) - PUC, São Paulo, 1994.

SANTOS, Milton; RIBEIRO, Ana Clara T. O retorno do território.In: SANTOS, M.; SOUZA, M. A.; SILVEIRA, M. L. (Orgs.). Território: globalização e fragmentação. São Paulo: Hucitec, Anpur, 1994.

SANTOS, Milton; SILVEIRA, Laura. O Brasil: território e sociedade no início do século XXI. Rio de Janeiro: Record, 2001.

SASSEN, Saskia. Global city. Princeton: Princeton University Press: 1991.

The new labor demand in global cities. In: SMITH, M. P. (Ed.). Cities in transformation: class, capital and the State. Beverly Hills: Sage, 1994. (Urban Affairs Annual Reviews, 25)

Artigo recebido em 12 de maio de 2006 e aprovado em 18 de julho de 2006. 